\title{
Digital Revolution or Digital Dominance? Regime Type, Internet Control, and Political Activism in East Asia
}

\author{
Min-Hua Huang and Wen Hong
}

Many studies have shown that Internet use may be a driver of real world political participation. However, we still have a lot to learn about the dynamics of this relationship. This article elaborates this relationship by exploring the effect of different types of Internet use (including social media) on participation in real world political activism. We also explain how two contextual factors - regime type (level of authoritarianism) and the level of government control over the Internet (level of Internet control) interact and affect the relationship between Internet use and political activism. Our findings in general corroborate the expected positive and significant relationship between Internet use and political activism. However, this relationship is highly contingent on how the level of authoritarianism and level of Internet control interact, producing two contrasting patterns of relationships between Internet use and political activism, labeled as "digital revolution" and "digital dominance." We find that one-party authoritarian regimes are closer to the "digital dominance" type, meaning that the interaction between regime type and Internet control weakens the relationship between Internet use and political activism; however, in limited democracies or democracies with excessive Internet control or authoritarianism, citizens' participation in political activism through online channels is emboldened, producing the "digital revolution" type. In democracies with little Internet control, citizens may have an incentive to participate in political activism through the Internet, but institutional rules that allow rotation of power might prevent either "digital dominance" or "digital revolution" from developing.

Key Words: internet use, political participation, regime type, internet control

*Min-Hua Huang(mhhuang5103@ntu.edu.tw) is professor at the Department of Political Science and the Director of the Center for East Asia Democratic Studies at National Taiwan University, Taipei, Taiwan. He received his Ph.D. from the University of Michigan. His research and teaching interests are in survey studies, Asian politics and multivariate statistical analysis.

**Wen Hong(wenhong@scut.edu.tw) is professor at the School of Public Administration at South China University of Technology, Guangzhou, China. He received his Ph.D. from Jilin University, China. His research and teaching interests are in local governance, social governance, government performance, and risk management. 
$\mathrm{I}_{\mathrm{p}}^{\mathrm{n}}$ recent years, following a broader global trend, the Internet has been popularized across East and Southeast Asia, spreading beyond the economically advanced countries in the region such as Japan, South Korea, and Taiwan, to its less developed economies. Even poorer countries in the region such as Vietnam, Philippines, and Myanmar have witnessed a rapid spread of Internet use over the past decade, particularly among their young population. ${ }^{1}$ Furthermore, there remains significant scope for even greater Internet penetration in the future as incomes rise and the costs of Internet technology falls. ${ }^{2}$ This growth will also be driven by generational effects, meaning that as the millennial generation who grew up surrounded by Internet technology ages, Internet use will become the new norm across generations.

With the global popularization of the Internet, an extensive literature has emerged discussing the implications of Internet technology for political participation. At the most fundamental level, the Internet offers new channels for communication and political organization (Baek, Wojcieszak, and Carpini 2012; De Zúñiga, Copeland, and Bimber 2014). For instance, the Internet for the first time offers the possibility of readily accessible and barrier-free communication, allowing ordinary people to successfully organize collective action, where as in the past such action would have only been possible through established organizations such as political parties, religious organizations, or trade unions (Farrell 2012). In the age of the Internet, collective action has been supplanted by "connective action," creating new possibilities for political mobilization (Bennett and Segerberg 2012). At the same time, social media has been blamed for stifling debate and worsening political polarization by dividing people into increasingly impenetrable "filter bubbles" of like-minded people into which alternative experiences or viewpoints rarely penetrate (Pariser 2012). Ironically, the Internet may offer us the possibility of communication and joint action with similarly-minded people, while at the same time closing us off from the possibility of exchanging views and experiences with people who think differently from us.

1 According to World Development Indicators (WDI), the number of mobile cellular subscriptions (per 100 people) in nine Asian LDCs has rapidly increased in the past ten years (2005-2015), for example, from 8.0 to 133.0 in Cambodia, from 11.4 to 53.1 in Laos, and from 0.3 to 76.7 in Myanmar. The WDI dataset is accessible online at http://data.worldbank.org/indicator/IT.CEL.SETS.P2 (November 26, 2016).

2 Before 2013, Internet costs, measured as a ratio of per capita GNI, were falling across the world. However, the decline in Internet costs started to slow down after 2013, and costs even increased in some developing countries. Nonetheless, the cost of Internet access both in real and absolute terms is substantially lower than a decade ago. See Truong (2015). 
However, while many studies have shown that the Internet use may be a driver of political participation (Tolbert and McNeal 2003; De Zúñiga, Jung, and Valenzuela, 2012), we still have a lot to learn about the dynamics of this relationship. For instance, is this relationship influenced by the type of Internet use (which might include both non-political and highly political online activities) and the type of political participation (which might include institutional channels of participation such as voting in elections to political activism outside of formal political institutions)? In addition, how is this relationship influenced by macrolevel factors such as regime type or the level of government control over the Internet? This study tries to answer these questions by exploring the relationship between different types of Internet and social media use and participation in real world political activism, and how this relationship is influenced by the interaction of regime type and level of Internet control.

\section{HOW DOES RISING INTERNET AND SOCIAL MEDIA USE AFFECT POLITICAL ACTIVISM?}

Internet and social media use is growing rapidly around the world, including in East and Southeast Asia. Data from the Internet Telecommunications Union (2015) and internet.org (2014) show that by 2015, $43.4 \%$ of the world's population were using the Internet, including $82.2 \%$ of those in developed countries and $35.3 \%$ of those in developing countries. In the Asia and Pacific region, $36.9 \%$ of the population used the Internet, while $42.3 \%$ had mobile broadband subscriptions. Beyond simply searching for and consuming information, with the advent of social media, Internet users are also increasingly using online spaces to form virtual communities and share user-created content. Figures from 2015 show that social media penetration has reached $43 \%$ in East Asia and 26\% in Southeast Asia, and that social media users in the region spend an average of up to four hours a day using social media (Go-Globe 2015).

In recent years, a growing academic literature has emerged exploring the effect of Internet and social media use on patterns of political participation. A number of studies have found that regular Internet use is associated with increased electoral and activist political participation (De Zúñiga, Puig-I-Abril, and Rojas 2009; Khondker 2011; Bimber 2014), although some studies find no relationship between regular Internet use and political participation (Davis 1999; Bimber 2001). In addition, Quintelier and Vissers (2008) find that while there is no relationship between time spent on the Internet and real world political participation, there is a significant association between certain online 
activities and offline political participation. Wang (2007) also finds that use of the Internet for political purposes in Asia increases feelings of trust and Asia, increasing participation in campaigns and politics. Regular Internet use may also be associated with a displacement effect in offline political participation, where people substitute institutionalized channels of political participation such as regular voting in elections for alternative channels of participation such as political activism or volunteering (Zukin et al. 2006). Alternatively, regular Internet users may choose to forego offline political participation altogether, replacing it with so-called "slacktivism" - online political participation that generates little more than a feel-good factor for its participants (Christensen 2011).

Of course, online spaces for political participation are contested. Internet censorship is becoming increasingly pervasive across the world as regimes seek to control the political impacts of Internet and social media use. Of the East Asian countries, Internet censorship is pervasive in China and Vietnam, and also widely used in Thailand, Cambodia, Malaysia, and Indonesia. ${ }^{3}$ While online censorship may make political information that does not conform to the official view harder to access and increase the risks involved in voicing one's opinion online, researchers have shown that even in countries with strict Internet censorship such as China, the Internet still serves as a space to disseminate views and criticize the government, and even to organize mass protests (Shih 2016). The cat and mouse game between the government and Internet users shows that government efforts to control online spaces may not always be successful, despite the investment of significant government resources in the maintaining and strengthening the Internet censorship regime. As Jason Q. Ng points out, "Internet users are clever, and with ever-growing information about how companies and governments censor content online, the mice will be harder to catch and silence" (quoted by Shih 2016). In short, while the government may wish to control online spaces, whether they are successful in doing so will depend on a number of factors including constitutional limits on the regime's ability to control the Internet as well as the capacity of the state to invest the necessary resources to enforce online controls.

We can identify several themes from the above discussion. First, Internet and social media use in the region is growing rapidly, and that many people use the Internet and social media to search for information about politics or express their political views. Second, the relationship between Internet use and political

${ }^{3}$ See the country profiles section of the OpenNet Initiative at http://opennet.net (November $26,2016)$. 
activism varies between different types of online and offline activity. Third, the relationship between Internet use and political activism may be mediated by government censorship of online spaces. In the sections below, we probe more deeply into these themes using data from the Fourth Wave of the Asian Barometer Survey (ABS), a comparative democratization survey carried out in fourteen countries and territories in East and Southeast Asia between 2014 and $2016 .^{4}$

\section{PATTERNS OF INTERNET USE AND POLITICAL ACTIVISM IN EAST ASIA}

While Internet use is becoming universal, people use the Internet for many purposes, often not involving politics. Even when people use the Internet for political purposes, this may be limited to passive use such as finding information about politics, or it may also include active use such as expressing opinions in online forums. Therefore, the most recent wave (Fourth Wave) of the Asian Barometer Survey includes four items designed to measure different levels of engagement with the Internet - (1) Internet use, (2) social media use, (3) use of the Internet (including social media networks) to find information about politics and government, and (4) use of the Internet (including social media networks) to express opinions about politics and government. The first two items are designed to capture all types of Internet and social media use, whereas the latter two items measure use of the Internet and social media for specifically political purposes.

On the left side of Figure 1, we show the average percentages for each of the four items in two categories of regime: democracies and limited democracies or one-party regimes. ${ }^{5}$ Our findings show that citizens in democracies are more likely to be Internet users (67\%) than their counterparts in limited democracies or one-party regimes (50\%). However, we suspect that this difference may be the

4 The Asian Barometer Survey (ABS) periodically conducts representative face-to-face surveys in East and Southeast Asian on citizens' political attitudes and behaviors. To date, data from four waves of the survey have been publicly released. For more details, please refer to the project's official website at http://www.asianbarometer.org/

5 As the next section shows, we define the three regime types by Freedom House score: democracy (1-2.5), limited democracy (3-5), and one-party regimes (5.5-7). In ABS surveys, only two countries are one-party regimes: China and Vietnam, and therefore we pool limited democracy and one-party regime in presenting the percentage of ICTs Use and political activism. In the later analysis, however, we separate the two types because the number of correlations in each type suffices to distinguish between the categories $(\mathrm{n}>=20)$. 
result of the lower levels of economic development found in most of the limited democracies and one-party regimes rather than the effect of the regime type itself. Interestingly, we find no difference between regime types in social media use, with reported usage of $45 \%$ under both regime types. Even on use of the Internet or social media to search for political information and using the Internet to express political opinions, regime type has little effect. In democracies, $31 \%$ of respondents had used the Internet or social media to search for political news compared to $29 \%$ of their counterparts in limited democracies and one-party regimes, while $12 \%$ of respondents in both regime categories used the Internet or social media to express political views. However, the finding could be interpreted in two ways. Citizens in limited democracies and one-party regimes may be using the Internet to find information critical of the government and express anti-government views, despite the pervasive censorship that exists in many countries and in some cases at significant risk to the individuals expressing their opinions online. However, individuals may be searching for political information that is supportive of the government's position, or going online to express views that are directly supportive of the regime, or to express nationalist sentiments that may indirectly help to maintain the continuing legitimacy of the regime.

Figure 1. ICT Use and Political Activism by Regime Type in East Asia

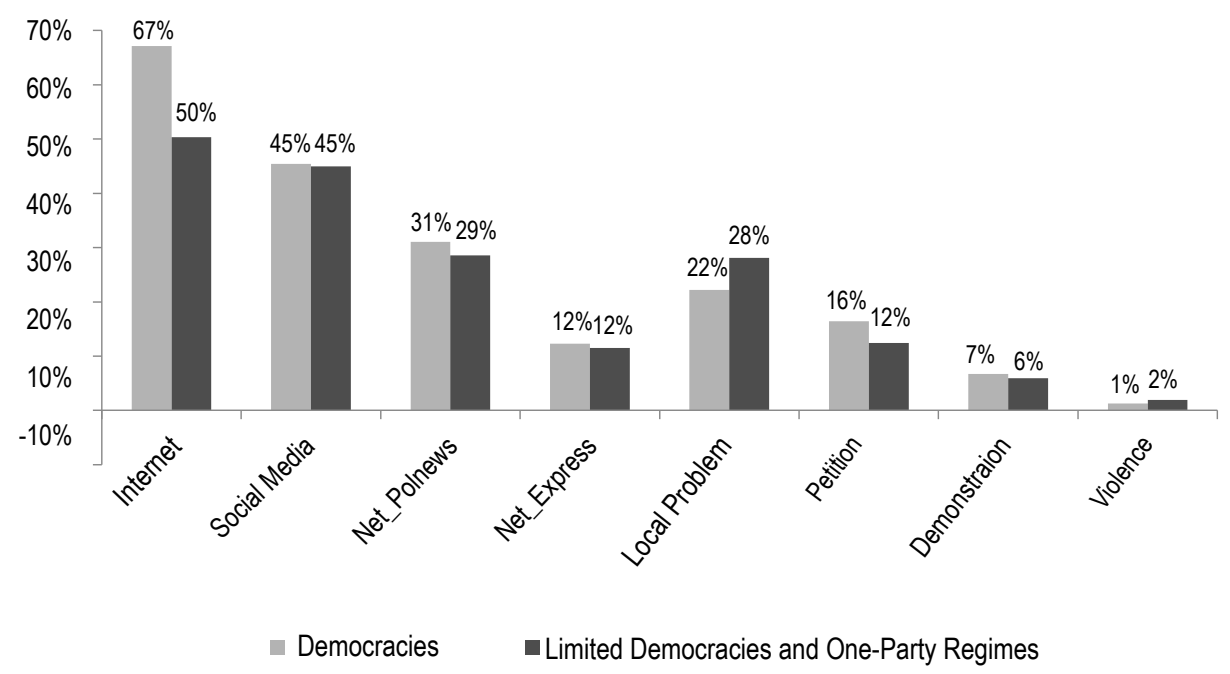

Note: The percentages are calculated based on country averages. None of the difference is significant at the $p \leqq 0.05$ level. The $17 \%$ difference in Internet usage is also not significant due to the large standard deviation in both regime categories.

Source: ABS 4 (2014-2016) 
The ABS also includes four items measuring different types of activist participation - ranging from peaceful forms of activism that are generally legal (getting together with others to solve local problems and signing a petition), to types of activism that directly challenge the system and may be illegal in many limited democracies or one-party regimes (participating in protests), and types of activism that are always illegal regardless of the regime type (use of violence for a political cause). As shown on the right side of Figure 1, citizens in limited democracies and one-party regimes are actually more likely to get together to solve local problems that their counterparts ( $28 \%$ in limited democracies and one-party regimes vs. $22 \%$ in democracies), suggesting that, at least at the local level, a lack of democracy does not undermine political efficacy. Next, citizens in democracies were more likely to raise a petition than their counterparts in limited democracies and one-party regimes (16\% in democracies vs. $12 \%$ in limited democracies and one-party regimes). However, participation in demonstrations ( $7 \%$ in democracies vs. $6 \%$ in limited democracies and one-party regimes) and political violence ( $1 \%$ in democracies vs. $2 \%$ in limited democracies and one-party regimes) was very low and showed little variation between category of regime.

The descriptive statistics show that there is little variation in patterns of Internet use and activist participation between regime types (none of the percentage differences are statistically significant). The next step of our analysis is to look at the relationship between different types of Internet use and activist participation. In Table 1, we show whether Internet use, social media use, using the Internet to find political information, and using the Internet to express political opinions have a statistically positive significant effect on each of the four types of political activism. For this analysis, our cases are divided into three regime types: democracies (Japan, South Korea, Taiwan, Mongolia, Philippines, and Indonesia), limited democracies (Thailand, Malaysia, Singapore, Hong Kong, Cambodia, and Myanmar), and one-party regimes (China and Vietnam). For each of the four types of Internet use, we show the number of cases where there is a statistically significant positive correlation with each type of political activism. For instance, in the upper left corner of the table, we look at whether Internet use is associated with higher levels of each of the four forms of participation in turn across each of the six countries belonging to the regime type, producing a total of twenty-four observations. ${ }^{6}$

6 The number of observations may not always equal the number of countries under each regime type multiplied by the four items measuring activist participation, because some items were not asked in some of the county surveys. 
Table 1. Bivariate Correlations between ICT Use and Political Activism in Asia

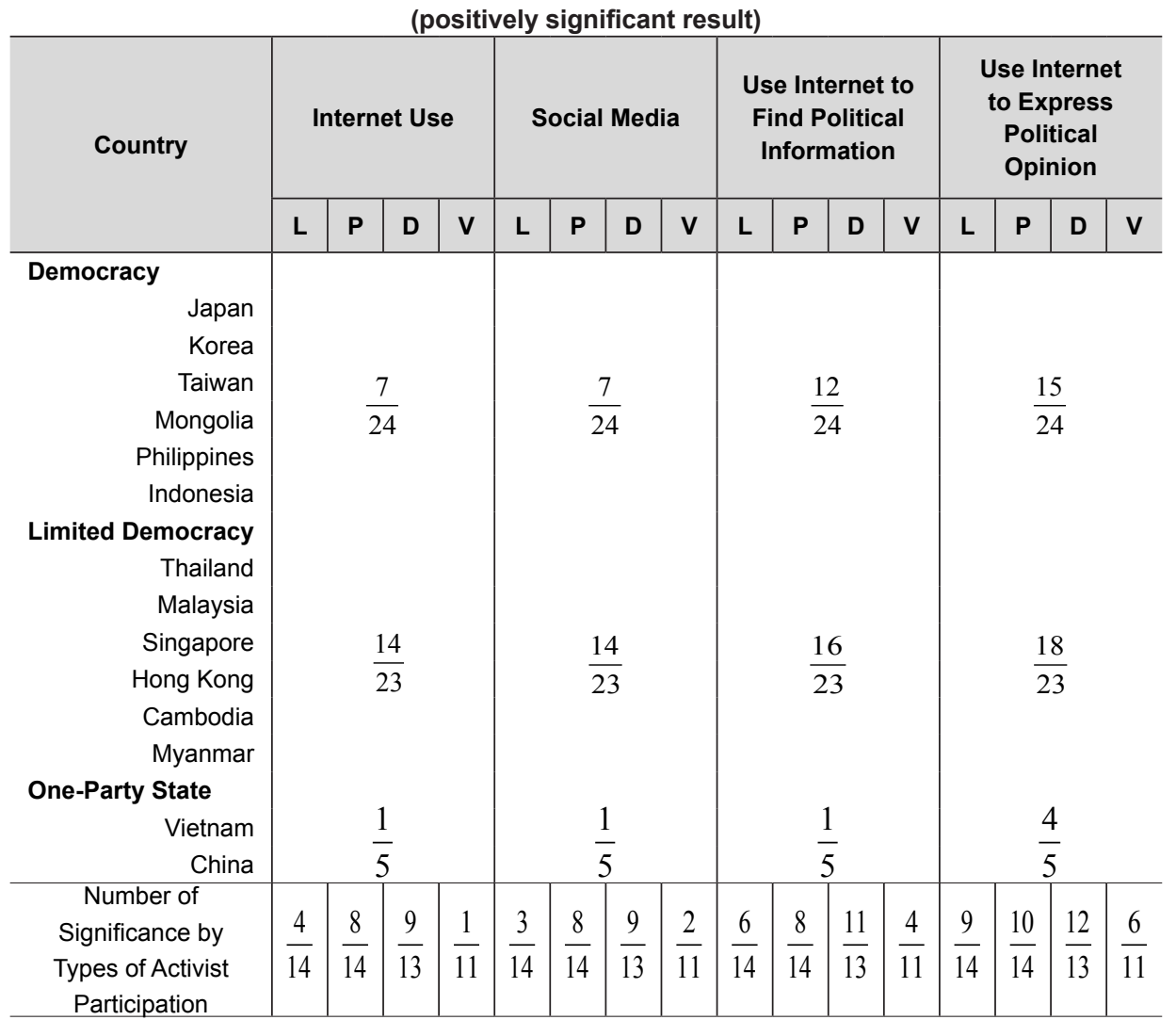

Note: Entry is number of significant bivariate positive correlations. Abbreviations of $L, P, D$ and $V$ represent "getting together with others to solve local problems", "signing a petition", "participating in protests", and "use of violence for a political cause", respectively.

Source: ABS 4 (2014-2016)

In the six democratic countries, Internet use and social media use have a statistically significant positive association with the four types of political activism in only seven of each of the twenty-four observations. For the specifically political use of the Internet to search for information about politics or to express political opinions, we found a statistically significant positive association on association with the four types of political activism in twelve and fifteen of the twenty-four cases respectively. As expected, using the Internet or social media for political purposes is more likely to produce offline political activism than use of Internet or social media for general purposes.

However, in the limited democracies, we find that Internet and social media 
use (both political and nonpolitical) have a much more consistent effect on real world political activism. Both Internet use and social media use have a statistically significant positive association with the four types of political activism in fourteen out of the twenty-three observations, double the number of statistically significant relationships found in the democracies. Furthermore, for use of the Internet to search for information about politics or to express political opinions, we found a statistically significant positive relationship in sixteen and eighteen of the twenty-three observations respectively, also representing a much more consistent pattern than the findings for democracies. This finding suggests that Internet and social media use may be an even more important driver of real world political activism in limited democracies or one-party regimes, in the same way that use of ICTs facilitates mass demonstrations during the Arab Spring.

While Internet use, social media use, and use of the Internet to find political information are only associated with the four types of political activism in out of the five observations in one-party regimes, use of the Internet to express political opinions is associated with the four types of political activism in four of the five observations. This suggests that in one-party regimes, people who are willing to take personal risks to express their opinions online are a self-selecting group who are also more likely to be involved in real world political activism. However, for general Internet and social media users, Internet and social media use is unlikely to generate greater real world political activism.

In addition, we look at the relationship between each form of Internet use and each form of political participation for all of the surveyed countries. We find that when Internet use is more explicitly political in nature, it has a greater number of significant correlations with participation in political movements that challenge the authority of the regime. In particular, for the most political form of online activity - expressing political opinions online - we even find a positive correlation with the use of violence for political purposes in more than half of the countries (six out of eleven). Furthermore, we find a positive correlation with getting together to solve local problems in nearly two-thirds of countries (nine out of fourteen), even though these activities are not strongly correlated with other forms of Internet use (only four and three out of fourteen in Internet use and social media use). Expressing opinions online is also found to be positively associated with signing a petition or joining a demonstration in more than twothirds of cases (ten and twelve out of fourteen), and these two forms of political participation show the strongest association with all forms of Internet and social media use. In fact, we only find one country where expressing political opinions online is not significantly associated with participation in protests. Such a result is very likely associated with self-selection effects involving the online activities 
of participants in political activism. This means that individuals who express political opinions online are also the same people who are the most willing to participate in political activism. Therefore, expressing political opinions online is positively associated with different forms of political activism in a large majority of cases.

\section{RESERCH DESIGN}

In the section above, we showed that the relationship between Internet use and political activism varies by regime type. Furthermore, from our review of the literature, we also anticipate that Internet control may have a salient effect on the relationship between Internet use and political activism. In order to further probe the effect of regime type and Internet control on the relationship between Internet use and participation in political activities which challenge the government, we apply various model specifications to analyze the correlation coefficients for the dependent variable using linear regressions. Two sets of group dummies are specified (types of Internet use and political activism) to measure their effect on online political expression and participation in demonstrations. Given that certain socioeconomic factors may strongly affect the association between Internet use and political activism, we add three variables to control the contextual environment: control of corruption (political), economic growth (economic), and national population (demographic). ${ }^{7}$ We assume that better socioeconomic conditions or more difficult demographic conditions for effective opposition (vast population) will weaken the positive correlation between Internet use and political activism. Our regression analysis focuses on how regime type and Internet control individually or jointly impact participation in Internet-based political activism.

To measure the two key variables, we apply Freedom House scores to measure regime type, taking the average of the scores for political rights and civil liberties. Scores range from 1 indicating the most democratic to 7 representing the least democratic. Since the overall score is produced by averaging scores for political rights and civil liberties, 0.5 scores are also possible, with scores between 1 and 2.5 indicating "free," scores of between 3 and 5 indicating "partly free,"

7 We also considered including GDP per capita (World Development Indicators) and government effectiveness (Worldwide Governance Indicators) as control variables. However, both variables are highly correlated with control of corruption (Worldwide Governance Indicators), with correlation coefficients of over 0.95 . 
and scores of between 5.5 and 7 indicating "not free," and can be employed as qualitative categories or a continuous quantitative index so that the parameters of the generalized linear model are easy to understand. To operationalize this measure, we subtract 1 from the Freedom House score, to measure the extent of authoritarianism, and also make corresponding adjustments to the categories. As to Internet control, we apply the Freedom on the Net (FOTN) score produced by Freedom House. This score is generated from three dimensions: obstacles to access, limits on content, and violations of user rights, which are weighted at 25,35 , and 40 points respectively, producing a total score of 100 points. Higher scores indicate greater government censorship of the Internet and less Internet freedom. In terms of categories, a score of o-30 means the Internet is "free," a score of 31-60 means the Internet is "partly free," and a score of 61-100 means the Internet is "not free." Although the overall score is on a continuous scale, each of the three dimensions are independently measured and tap into a different aspect of censorship. "Obstacles to access" means restrictions on access the Internet including government restrictions on the activities of telecommunications operators or network providers. "Limits on contents" refers to government led Internet censorship restricting online content, preventing users from accessing information banned by the government, as well as preventing people using the Internet to organize collective action. "Violations of user rights" refers to subsequent legal prosecutions or administrative actions, which aim at deterring Internet users from going beyond boundaries of acceptable Internet use set by the government, and enabling the government to exercise full control over Internet use. Full details of the operationalization of variables can be found in the appendix.

In terms of causal hypotheses, we expect the greater the democratization of the political system, the less likely people are to engage in political activism through the Internet to influence the government since regular elections or other participatory channels give citizens the opportunity to influence government policy and even decide whether the government can remain in office. ${ }^{8}$ Therefore, except in the case of a major crisis, people do not need to engage in political action outside of the system using the Internet to exert influence over the government. However, in less democratic or more authoritarian systems, it is very difficult to use political institutions as a channel for bringing about changes in the government. As a result, citizens have a greater incentive to use the Internet to organize outside of the system in order to produce political change. trolled.

8 All the hypotheses should be interpreted under the condition that other things are being con- 
In this case, only pressure from outside the system can force the government to respond to popular demands and make policy changes, or even produce a restructuring or replacement of the incumbent regime.

\section{Hypothesis 1: Greater levels of authoritarianism produce a stronger positive correlation between Internet use and political activism.}

Regarding the Internet control hypothesis, we expect that a higher degree of government control will weaken the correlation between Internet use and political activism. This is because the greater the intensity of government control over the Internet, the greater its ability to prevent political activities that take place outside the system. In fact, when people in society realize that online spaces are controlled and monitored by the government, they are more likely to understand that the Internet no longer has the advantage of privacy, and may become a source of information for the government to prevent political opposition from effectively organizing. Therefore, a greater level of Internet control produces a weaker correlation between Internet use and political activism.

\section{Hypothesis 2: Greater levels of Internet control produce a weaker positive correlation between Internet use and political activism.}

In the above hypotheses, we consider the complex interaction between regime type and Internet control. The following two examples can be used to illustrate the relationship between Internet use and political activism, which may be both affected by the level of political authoritarianism and the degree of Internet control. In the first case of a fully democratic polity, because the constitution guarantees civil liberties and political rights, if a government violates online freedom through regulation of the Internet, citizens may use the Internet to challenge the regime politically from outside the system. In this example, there is a positive association between Internet use and political activism. In the second case of a highly authoritarian regime, because citizens' civil liberties and political rights are not protected, a higher degree of government regulation of the Internet will increase awareness among citizens of the dangers of Internet use, and especially of any online activities designed to challenge the government. Therefore, there will be a weaker relationship between Internet use and political activism, or even a negative relationship. In other words, political activities designed to influence the government from outside the system will avoid using 
the Internet so as not to arouse suspicions or divulge information.

We can fix the level of Internet control at the highest and lowest level to examine the different effects of regime type under each situation. For example, provided that a regime does not regulate the Internet at all, when a country is more authoritarian and suppression of citizens' freedoms and political rights is more serious, people will be more likely to use the Internet to organize and participate in political activities against the government because the regime does not control or restrict information on the Internet about these activities. However, provided that a country's rulers fully control online spaces and do not allow any online freedom, when the regime is also highly authoritarian, using the Internet to challenge the government's actions is tantamount to walking into a trap. Nevertheless, if the government does engage in stricter Internet censorship but the regime has to abide by the democratic rules, people are more likely to use the Internet to initiate and participate in opposition activities against the governing authority in protest against encroachment of their rights of online freedom. The above discussion indicates that the correlations between Internet use and political activism are contingent on their respective intensities, and therefore, their relationship may be better captured by specifying an interaction term.

Hypothesis 3: The regime's level of authoritarianism and government's control over the Internet interact simultaneously to influence the correlations between Internet use and political activism.

\section{STATISTICAL FINDINGS}

Table 2 shows the statistical findings for eight different models in the regression analysis. First, we control types of Internet use and political activism, applying categorical measures of regime type and Internet freedom to evaluate the outcomes of the correlations under different pairs. Model 1 and 2 compare the basic settings of the regression with or without control of the three contextual variables. Second, we consider the two factors of regime type and Internet control and their joint effect on the relationship between Internet use and political activism. Model 3 and 4 are specified to test which of the categorical or continuous measures of the two explanatory variables better explains the variance in the dependent variable, and whether the three hypotheses are falsified or corroborated. Finally, in Model 5 to 8, we divide Internet control 
into three sub-dimensions which we substitute for the overall index of Internet control in order to evaluate whether different types of regulation have different political effects.

Before discussing the findings of each model, we first check if the control variables behave in the same way as we found in Table $1 .{ }^{9}$ In each of the eight models in Table 2, the findings for the control variables regarding types of Internet use and political activism are consistent. Of the categories of Internet use, expressing political opinion online has the highest correlation, followed by finding political information, while the frequency of Internet use and social media use have no significant correlation with the level of activist participation. As for categories of activist participation, joining a demonstration has the largest correlation, followed by signing a petition, while the Internet use is not significantly correlated with resolving local problems and use of violence. Both results are very similar to the patterns of bivariate correlations, with a trivial difference that the correlations between the use of violence and all four types of Internet use, after being controlled in multivariate regressions, have greater predicted values than their counterparts associated with solving local problems. ${ }^{10}$

First, we discuss the results for the basic model setups in Model 1 and 2. The major difference is whether adding the three contextual variables for control purposes can increase the explanatory power of the model. As shown in Table 2 , while adding the three contextual variables does improve explained variance by $4.7 \%$ in terms of adjusted R-squared, the signs and significance levels of the two explanatory variables, the categorical measures of regime type and Internet control, only show mixed corroborated findings at best. For both models, the corroborated finding for Hypothesis 1 should show both regression coefficients of Limited Democracy and One-Party Regime as positively significant, and the latter should be larger in magnitude. However, only the coefficient of Limited Democracy in Model 1 produced the expected result. Similar findings can be concluded with respect to the variable of Internet control. As can be seen, the corroborated finding for Hypothesis 2 should show both negative coefficients of Internet Partly Free and Internet Not Free. However, in Model 1, only the coefficient of Internet Partly Free is consistent with this expectation. A straightforward interpretation is that contextual variables should be

9 For the simplicity of presentation, we do not report the regression result for the control variables regarding types of Internet use and political activism.

10 This difference maybe attributed to the change from a bivariate to multivariate model. Given the fact that all of the eight models show very minor differences, we argue that this minor variation is reasonable in the context of changes in the model specification. 
Digital Revolution or Digital Dominance? | 233

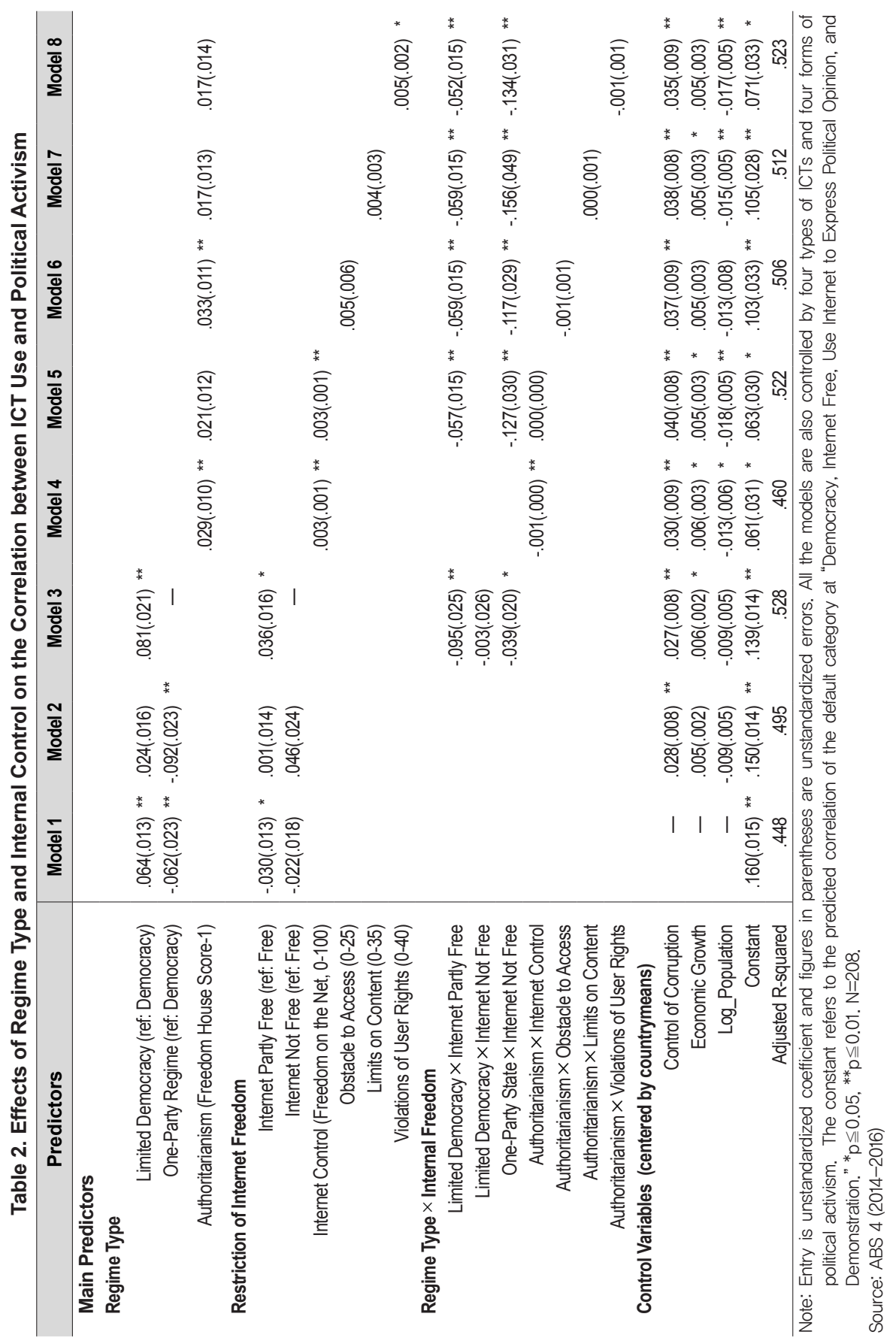


incorporated. However, it appears that there are certain complex relationships between regime type and Internet control. Since both Model 1 and Model 2 fail to specify that relationship, we need to conduct another test by adding the interaction term of regime type and Internet control as Hypothesis 3 suggests.

Considering the possibility that the failure to corroborate Hypothesis 1 and 2 might not be just a misspecification problem but could be a measurement one, we apply both categorical and continuous measures of regime type and Internet control to specify an interaction model. As shown with Model 3 and 4 in Table 2, when we apply the categorical measures, all the country cases fall into one of six combinations-Democracy with Free or Partly Free Internet, Limited Democracy with Free, Partly Free, Not Free Internet, and One-Party Regime with Not Free Internet. In this model setting (Model 3), these six combinations, which require group dummies, fully cover the existent country cases regarding the interaction between regime type and Internet control. On the other hand, if we apply the continuous measures of both explanatory variables, the model setting will be slightly simpler, as in Model 4 where only three variables are specified (Authoritarianism, Internet Control, and their interaction). The results of Model 3 primarily convey two important findings. First, the explanatory power is significantly elevated from $49.5 \%$ to $52.8 \%$, indicating a better specification when the interaction terms (here means the five group dummies) are incorporated. Second, when we convert the regression result into the predicted correlations, as shown in Table 3, we can clearly see lower predicted correlations in the diagonal line, which includes three country categories, Democracy with Free Internet, Limited Democracy with Partly Free Internet, and One-Party Regime with Not Free Internet. This means that the correlations between Internet use and political activism are at a lower level when the three regime types match the three levels of Internet control. Deviation from the diagonal cells will result in a rise in the level of correlation, regardless of whether the level of authoritarianism or Internet control increases or decreases. If we employ the continuous measures of regime type and Internet control as Model 4 shows, the result clearly indicates that the explanatory variance is significantly lower (46\%) when compared to Model 3. Nevertheless, the two explanatory variables and their interactions are all significant, confirming the expectations of Hypothesis 3. As the visualization of the regression result of Model 4 in Figure 2 shows, the predicted correlation between Internet use and political activism is simultaneously contingent on the level of authoritarianism and Internet control. When a country is significantly less authoritarian, greater Internet control will increase the magnitude of the positive correlation between Internet use and political activism; but greater Internet control will decrease the magnitude of the positive correlation when the 
country becomes highly authoritarian. Similar expositions can be made by fixing the level of Internet control and varying the level of authoritarianism. Model 4 suggests that Hypothesis 3 is corroborated rather than Hypotheses 1 and 2.

Figure 2. Effects of Regime Type and Internet Control on Online Activism (Freedom on the Net Index)

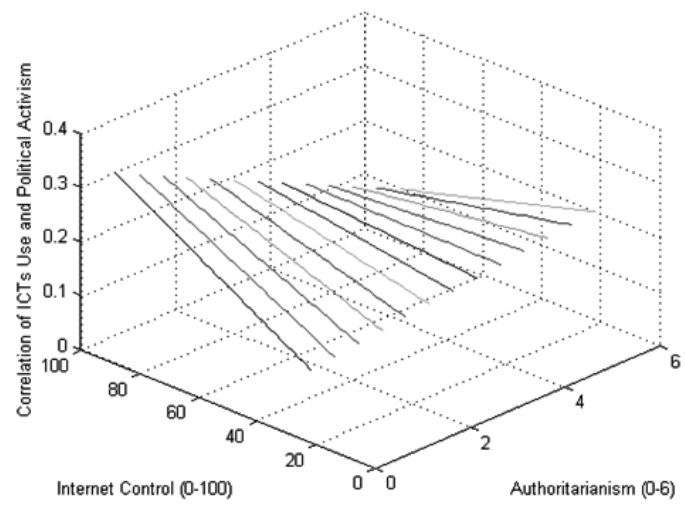

Table 3. Online Political Expression and Social Activism by Regime Type and Internet Freedom

\begin{tabular}{cccc}
\hline $\begin{array}{c}\text { Level of Internet } \\
\text { Freedom (FOTN) }\end{array}$ & $\begin{array}{c}\text { Democracy } \\
\text { (FHS=1-2.5) }\end{array}$ & $\begin{array}{c}\text { Limited Democracy } \\
\text { (FHS=3-5) }\end{array}$ & $\begin{array}{c}\text { One Party State } \\
\text { (FHS=5.5-7) }\end{array}$ \\
\hline Free & \multicolumn{2}{c}{ Local Problem } & - \\
Partly Free & $0.047^{* *}$ & $0.128^{* *}$ & - \\
Not Free & $0.082^{* *}$ & -0.048 & 0.007 \\
\hline Free & - & 0.043 & - \\
\hline Partly Free & Petition & - \\
Not Free & $0.108^{* *}$ & $0.189^{* *}$ & $0.068^{* *}$ \\
\hline Free & $0.144^{* *}$ & 0.013 & - \\
\hline Partly Free & - & $0.105^{* *}$ & - \\
Not Free & Demonstration & $0.100^{* *}$ \\
\hline Free & $0.139^{* *}$ & $0.221^{* *}$ & - \\
Partly Free & $0.175^{* *}$ & 0.044 & - \\
Not Free & - & $0.136^{* *}$ & 0.018 \\
\hline
\end{tabular}

Note: Predicted correlations are calculated based on the result of Model 3 (with baseline profile) in Table $2 .{ }^{*} \mathrm{p} \leqq 0.05,{ }^{* *} \mathrm{p}$ $\leqq 0.01 . \mathrm{N}=208$.

Source: ABS 4 (2014-2016) 
While both the results of Model 3 and 4 indicate a complex picture of how regime type and Internet control affect the correlation between Internet use and political activism, one apparent discrepancy is that Model 3 has stronger explanatory power and predicts much lower correlations in all of the diagonal cells, contradicting the apparent increased level predicted by Model 4 in Figure 2. However, given the lower explained variance, it is very likely that the specification of Model 4 fails to capture the findings of lower diagonal correlations identified by Model 3. It is therefore necessary to add two group dummies (specifying the two diagonal categories, Limited Democracy with Partly Free Internet and One-Party Regime with Not Free Internet) to Model 4 to show whether the new model exhibits the same level of explanatory power. As Model 5 in Table 2 shows, if we apply continuous measures of regime type and Internet control with two diagonal categories, the explained variance matches Model 3 , with only a trivial difference $(52.2 \%$ vs. $52.8 \%)$. This indicates that Model 5 has corrected the specification error and its regression result reflects a more accurate test of the three hypotheses. While most of the coefficients are similar to the findings in Model 4 in terms of both signs and significance levels, the interaction term between level of authoritarianism and Internet control is not significant. This means, when controlling for the lower correlations of the diagonal categories, only Internet control significantly explains the variation of the correlations, but in a positive direction against the expectation of Hypothesis 2. Considering that the empirical variation of level of Internet control in ABS 14 countries mostly comes from democracies and limited democracies, this finding shows that Internet control is associated with a greater incentive for people to use the Internet for activist political participation, as long as the regime is not extremely authoritarian.

One way to unravel the meaning of the above findings regarding Internet control is to decompose the overall measures into the three composite elements, producing a wider variation between the three regime types. For instance, Vietnam has a greater level of Internet control $(\mathrm{FOTN}=76)$ than Cambodia $($ FOTN $=48)$, but it has a lower rating on obstacles to access (13 vs. 14). The reason for Vietnam's higher overall rating is found in limits on content and violations of users' rights. In the next section, we will focus on how specific dimensions of Internet control explain the complex relationship between Internet use and political activism found in Model 5. 


\section{HOW DO DIFFERENT METHODS OF INTERNET CONTROL AFFECT THE USE OF ICTS FOR POLITICAL ACTIVISM?}

In this section, we use the results from Model 5 as a benchmark for comparison between three different models (Model 6-8) in which the specification is the same but the measure of Internet control is replaced by each of the three composite elements: obstacles to access, limits on content, and violation of user rights. These three dimensions refer to different approaches adopted by governments to regulate online space. It is possible that despite democratic rules, democratic governments may be involved in Internet control on all three dimensions. Likewise, authoritarian governments may exert little influence over the three dimensions of Internet control. Applying different indices enables us to understand how different types of Internet control affect the relationship between ICTs use and political activism.

Obstacles to access refers to government measures to restrict access to the Internet, including lack of infrastructure, prohibitive costs, or restrictive ICT connectivity. Obstacles to access restrict the channels, domains, or conditions (e.g. affordability) of Internet use. Measures in this category can be employed to prevent potential political opposition from emerging. Even when access is intentionally and unfairly regulated, Internet users may be unaware of or accustomed to restrictions. Therefore, obstacles to access may be a very effective measure of Internet control when they are passively accepted by the population. However, excessive use of these measures may impact a country's overall development due to the vital importance of ICTs for the modern economy.

As Model 6 in Table 2 shows, when replacing the overall FOTN measure with the measure of obstacles to access, we find the result significantly differs from Model 5. The level of authoritarianism now becomes positively significant as predicted by Hypothesis 1, but obstacles to access did not produce significant findings when interacting with the level of authoritarianism. This suggests that enforcing control over the Internet by creating obstacles to access does not by itself prevent individuals from using in the Internet to engage in political activism. However, it is also not found to motivate citizens to use the Internet to oppose the government. Under this condition, it is the increase of authoritarianism which produces a significant impact on the use of the Internet for political activism. This finding has an important theoretical implication: it is not just the level of Internet control which affects whether people use the Internet to oppose the government; the method of Internet control also matters.

Limits on content refers to measures adopted by the government to blocks or filter Internet or ICT content, including the removal unwanted online materials, 
as well as encouraging self-censorship or manipulating public opinion, and the imposition of constraints or incentives to force serve providers to cooperate with government efforts to control online spaces. These actions are often justified in name of national security and law and order, particularly in authoritarian or one-party regimes. Even in democracies, the government may have some scope to limit online content. Therefore, limits on Internet or ICT content may be seen as legitimate by the public. As Model 7 in Table 2 shows, when the Limits on Content score is used to replace the FOTN measure, we found that neither the level of Authoritarianism nor Internet Control has significant explanatory power, and their interaction is also not statistically significant. This confirms that citizens may not believe that government efforts to limit online content are excessive or unjustified.

The third indicator of Internet control is violations of user rights, which measures the legal, financial, political, or even physical violations of the rights of Internet users. This indicator is designed to capture the "fear factor" resulting from government prosecution, intimidation, retaliation, and even violent repression against users. A higher score on the violations of user rights measure suggests that people are subject to a great risk of encroachment on their rights as a result of their Internet use. As Model 8 makes evident, when we adopt this score as the measure of Internet control, the result is consistent to what we found in Model 5 when used the overall FOTN measure. For the two main explanatory variables, violations of user rights have a positive and significant effect on the relationship between Internet use and political activism. In light of the previous discussion on the findings of Model 3 and 5, we can summarize the outcome of Model 8 as follows: (1) violations of user rights is the most effective measure of Internet control and determines the regression result when the composite overall measure is applied. (2) each regime type has a corresponding optimal level of Internet control that can generate lower correlation between Internet use and political activism as shown in the three diagonal cells in Table 3. (3) In these three diagonal cells, correlations between Internet control and political activism from high to low are as follows: Democracies with Free Internet, Limited Democracies with Partly Free Internet, and One-Party Regime with Not Free Internet. (4) When controlling for other factors, we find that greater violations of user rights are significantly related to stronger positive correlations between Internet use and political activism, because citizens respond to violations of their rights by making demands for political change. This finding seems to contradict the result of Model 6, but it actually resonates since the factor that arouses political activism shifts to level of authoritarianism when the obstacles to access measure, which fails to capture the intrusive features of Internet control, 
replaces the overall measure FOTN or the indicator of violations of rights in regression analysis.

Finally, regarding the contextual control variables, only Population shows the expected negative relationship to the correlations, which suggests the larger the population, the weaker the positive correlation between Internet use and political activism due to the greater challenges involved in organizing effective opposition in a larger country. Control of Corruption and Economic Growth both have significant positive effects. These findings contradict our expectation that improved government performance will reduce incentives to protest the government through the Internet. However, we have noted that control of corruption is highly correlated to GDP per capita and government effectiveness measures, and thus, may reflect the emergence of more critical citizens in the context of higher levels of economic development (Norris 1999). A similar interpretation can be applied to the positive coefficient of economic growth, indicating that economic prosperity may produce more social mobilization that is likely to result in more political activism through the Internet. Finally, we do not want to over-interpret the results from the control variables in this study, but rather open up possibilities for future research to develop more sophisticated explanations.

\section{DIGITAL REVOLUTION OR DIGITAL DOMINANCE?}

How can we make sense of all the findings from Model 3 to 8 in Table 2? First of all, we can confidently conclude for each type of regimes there exists a corresponding optimal level of Internet control that generates the least correlation between Internet use and political activism. How can we explain the presence of this optimal level? We believe the answer is associated with the balance between "chilling effects" and "disempowerment effects." The chilling effect refers to the fear factor produced by Internet control, while the disempowerment effect denotes the dwindling capability of people to oppose the government due the institutional constraints of authoritarianism. When both the levels of Internet control and authoritarian are low, people have much less incentive to protest because they have the option of voting the government out in regular elections. However, if citizens are not willing to wait until the next election, a greater positive correlation between Internet use and political activism may emerge. The composite result gives a correlation of between 0.047 to 0.139 (shown in the top-left cells of Table 3) depending on type of political activism. When Internet control and authoritarianism increase to the middle 
level, people understand that they are subject to a certain level of repression by the regime, and also that their capacity to protest is restricted. This will further deter people from challenging the government through the Internet, producing a significant negative coefficient for Limited Democracy $\times$ Internet Partly Free, shown in Model 5 to 8 . When Internet control and authoritarian are both very high, the correlation between Internet use and political activism declines even further as shown from the much larger negative and significant coefficient in One-Party Regime $\times$ Internet Not Free.

What about the cases of the off-diagonal cells where the chilling and disempowerment effects show imbalance? Their correlations are higher than those of the diagonal cells because the incentive to oppose the government by using the Internet is increased either due to an insufficient disempowerment effect (too much Internet control), or an insufficient chilling effect (too much authoritarianism). In the former case, when the government is too forceful in implementing control, causing significant violations of user rights, people may be more motivated to challenge the government. In this case, citizens react against the excessive chilling effect as long as they have enough capacity to challenge it. On the other hand, when the chilling effect is relatively small but the agency of ordinary people is subject to authoritarian restrictions, the incentive to oppose the government through Internet use also increases because people have little to lose and much to gain in fighting for their civil rights and political freedom.

The main result of our analysis signals both "digital revolution" and "digital domination" phenomena as delineated in the above explanations for the off-diagonal and diagonal cells. The crucial factor is the regime's level of authoritarianism and the intensity of official Internet controls. When the state produces a chilling effect by increasing Internet controls, or fails to produce a chilling effect while behaving in an authoritarian manner, digital revolution is likely occur because people will fight to reduce the chilling effect or political authoritarianism. However, when level of Internet control matches the level of authoritarianism, the chilling and disempowerment effects act together to deter people from challenging state authority through online spaces. This pattern of "digital dominance" is frequently found in limited democracies with partly free Internet and one-party regimes with unfree Internet. For democracies with free Internet, the magnitude of the correlations depends on to the desire of people to change the government through regular elections or activist movements.

Finally, our analysis also finds the composing measures of Internet controls may not generate the chilling effects individually. When Internet control refers to obstacles to access, this does not produce a "fear" factor, meaning that there 
is no deterrent effect on political action. The effect regarding limits on content is not at all clear due to the complex nature of the concept. Violations of user rights, on the other hand, truly captures the essence of the "fear" factor, producing the chilling effect as the key factor in the relationship between Internet use and political activism.

\section{CONCLUSION}

The convenience offered by the Internet is already having a profound influence on the way people live their lives. We expect that in the future, people will use the most convenient and lowest cost method to participate in politics. This will strengthen the relationship between different forms of Internet use and political activism, particularly in the relationship between self-selecting online expression and demonstrations which challenge the government. The findings from our study show that regardless of whether the polity is a democracy, a limited democracy, or a one-party authoritarian regime, there is a strong association between Internet use and political activism. As network communications technologies enter all aspects of our everyday lives, this will become the new pattern for civic activism.

Despite this, we found that the association between Internet use and political activism is influenced by contextual factors, in particular the level of authoritarianism and degree of Internet control. The results from our analysis of different models show that violation of user rights is the most powerful indicator of the three dimensions of Internet control, meaning that the threat of future prosecution has a much greater chilling effect than obstacles to access or content restrictions. In addition, the disempowerment effect resulting from the institutional restriction of authoritarian regimes also suppresses people's incentive to pursue opposition against government through online channels. When both effects are on par with each other, Internet use and political activism have the least correlation, showing the phenomenon of "digital dominance" as the chilling and disempowerment effects increase. However, when the two effects are not at a corresponding level, people may experience insufficient chilling or disempowering effects, leading them to use the Internet for political activism and producing a "digital revolution" effect.

Both "digital dominance" and "digital revolution" show that the advance of network communications technology will have a significant influence on political participation in the future. However, this effect is both sophisticated and subtle, and should be understood in different contexts and political 
situations. This article shows that under different regime types and levels of Internet control, the capacity of the state to respond to opposition challenges can largely explain the relationship between Internet use and political activism. In democratic countries, state capacity is restricted by public opinion and the rule of law. People expect the government not to conduct Internet control, and have limited incentive to use the Internet for political activism that aims to change the government because this desired outcome can be achieved through regular elections. In limited democracies, people are aware that their online activities may be closely monitored and their political freedom and civil liberties are restricted. This political context further attenuates incentives to pursue opposition against the governing authority through Internet use due to the political risks involved. When the state exerts full control of the Internet and the extreme authoritarianism has preempted any space for effective political opposition, as is found in one-party regimes, the Internet loses its function as a platform for political mobilization beyond the reach of the state. Under this regime type, the risks of using the Internet to mobilize against the government are extremely high, and political opposition will avoid dependence on the Internet due to the fears that it will expose its activities to the regime.

\section{REFERENCES}

Baek, Young Min, Magdalena Wojcieszak, and Michael X. Delli Carpini. 2012. "Online versus Face-to-Face Deliberation: Who? Why? What? With What Effects?" New Media \& Society 14(3), 363-383.

Bennett, W. Lance and Alexandra Segerberg. 2012. "The Logic of Connective Action.” Information, Communication \& Society 15(5), 739-768.

Bimber, Bruce. 2001. "Information and Political Engagement in America: The Search for Effects of Information Technology at the Individual Level." Political Research Quarterly 54(1), 53-67. . 2014. "Digital Media in the Obama Campaigns of 2008 and 2012: Adaptation to the Personalized Political Communication Environment." Journal of Information Technology \& Politics 11(2), 130-150.

Christensen, Henrik Serup. 2011. "Political Activities on the Internet: Slacktivism or Political Participation by Other Means?" (First Monday, February 2011). Accessed at http://firstmonday.org/ojs/index.php/fm/ article/view/3336/2767 (July 26, 2017).

Davis, Richard. 1999. The Web of Politics: The Internet's Impact on the American Political System. New York: Oxford University Press. 
De Zúñniga, Homero, Gil, Eulàlia Puig-I-Abril, and Hernando Rojas. 2009. "Weblogs, Traditional Sources Online and Political Participation: An Assessment of How the Internet Is Changing the Political Environment." New Media \& Society 11(4), 553-574.

De Zúñniga, Homero, Gil, Nakwon Jung, and Sebastián Valenzuela. 2012. "Social Media Use for News and Individuals' Social Capital, Civic Engagement and Political Participation." Journal of ComputerMediated Communication 17(3), 319-336.

De Zúñniga, Homero, Gil, Lauren Copeland, and Bruce Bimber. 2014. "Political Consumerism: Civic Engagement and the Social Media Connection." New Media \& Society 16(3), 488-506.

Farrell, Henry. 2012. "The Consequences of the Internet for Politics." Annual Review of Political Science 15(1), 35-52.

GO-Globe. 2015. "Social Media Usage In Asia - Statistics And Trends [Infographic]." GO-Globe. Accessed at http://www.go-globe.com/blog/ social-media-asia/ (November 19, 2016).

International Telecommunication Unions. 2015. "ICT Facts and Figures, 2015." Accessed at http://www.itu.int/en/ITU-D/Statistics/ Documents/facts/ICTFactsFigures2015.pdf. (March 31, 2016).

Internet.org. 2014. "State of Connectivity, 2014: A Report on Global Internet Access." Accessed at https://fbnewsroomus.files.wordpress. com/2015/02/state-of-connectivity_3.pdf. (March 31, 2016).

Khondker, Habibul Haque. 2011. "Role of the New Media in the Arab Spring." Globalizations 8(5), 675-679.

Norris, Pippa. 1999. Critical Citizens. Oxford, UK: Oxford University Press. Accessed at http://www.oxfordscholarship.com/view/10.1093/019829 5685.001.0001/acprof-9780198295686 (March 31, 2016).

Pariser, Eli. 2012. The Filter Bubble: How the New Personalized Web Is Changing What We Read and How We Think. Reprint edition. London: Penguin Books.

Quintelier, Ellen and Sara Vissers. 2008. "The Effect of Internet Use on Political Participation An Analysis of Survey Results for 16-Year-Olds in Belgium.” Social Science Computer Review 26(4), 411-427.

Shih, Jocelyn. 2016. "Internet Censorship: The Double-Edged Sword of the Chinese Communist Party." SIR Journal. Accessed at http://www. sirjournal.org/research/2016/3/14/internet-censorship (November 19, 2016).

Tolbert, Caroline J. and Ramona S. McNeal. 2003. "Unraveling the Effects of the Internet on Political Participation?" Political Research Quarterly 
$56(2), 175^{-185}$.

Truong, Alice. 2015. "The State of Internet Connectivity around the World." World Economic Forum. Accessed at https://www.weforum.org/ agenda/2015/12/the-state-of-internet-connectivity-around-the-world/ (November 28, 2016).

Wang, Song-In. 2007. "Political Use of the Internet, Political Attitudes and Political Participation." Asian Journal of Communication 17(4), 381395 .

Zukin, Cliff, Scott Keeter, Molly Andolina, Krista Jenkins, and Michael X. Delli Carpini. 2006. A New Engagement?: Political Participation, Civic Life, and the Changing American Citizen. Oxford and New York: Oxford University Press.

[Received May 30, 2017; Revised June 15, 2017; Accepted July 19, 2017] 
Appendix: Variable Construction and Operationalization

\begin{tabular}{|c|c|c|}
\hline Variable & Questionnaire (ABS IV question id) & $\begin{array}{l}\text { Scale } \\
\text { (Range) }\end{array}$ \\
\hline \multicolumn{3}{|l|}{ ICTs Use } \\
\hline Internet Use & - How often do you use the internet? (q49) & Likert $(1,8)$ \\
\hline Social Media & $\begin{array}{l}\text { Do you currently use any of the following social media } \\
\text { networks? (q50) }\end{array}$ & Binary $(0,1)$ \\
\hline $\begin{array}{l}\text { Use Internet to Find } \\
\text { Political Information }\end{array}$ & $\begin{array}{l}\text { How often do you use the Internet or social media networks } \\
\text { to find information about politics and government? (q51) }\end{array}$ & Likert $(1,6)$ \\
\hline $\begin{array}{l}\text { Use Internet to } \\
\text { Express Political } \\
\text { Opinion }\end{array}$ & $\begin{array}{l}\text { How often do you use the Internet or social media networks } \\
\text { to express your opinion about politics and government? } \\
\text { (q52) }\end{array}$ & Likert $(1,6)$ \\
\hline \multicolumn{3}{|l|}{ Political Activism } \\
\hline Solve Local Problem & $\begin{array}{l}\text { Whether you personally have ever got together with others } \\
\text { to try to resolve local problems (q111) }\end{array}$ & Likert $(1,3)$ \\
\hline Signing a Petition & $\begin{array}{l}\text { Whether you personally have ever got together with others } \\
\text { to raise an issue or sign a petition (se13a) }\end{array}$ & Likert $(1,3)$ \\
\hline $\begin{array}{l}\text { Participating in a } \\
\text { Protest }\end{array}$ & $\begin{array}{l}\text { Whether you personally have ever got together with others } \\
\text { to raise an issue or sign a petition (se13a) }\end{array}$ & Likert $(1,3)$ \\
\hline Use Violence & $\begin{array}{l}\text { Whether you personally have ever got together with others } \\
\text { to raise an issue or sign a petition (se13a) }\end{array}$ & Likert $(1,3)$ \\
\hline \multicolumn{3}{|l|}{ Main Predictors } \\
\hline Regime Type & $\begin{array}{l}\text { Free House Score (average score of political right and civil } \\
\text { liberty rating, Freedom House) }\end{array}$ & $1 \sim 7$ \\
\hline Internet Control & $\begin{array}{l}\text { Freedom on the Net Score (summed score of obstacle to } \\
\text { access, limits on content, and violations of user rights, } \\
\text { Freedom House) }\end{array}$ & $0 \sim 100$ \\
\hline \multicolumn{3}{|l|}{ Control Variables } \\
\hline Control of Corruption & $\begin{array}{l}\text { Index of Control of Corruption (Worldwide Governance } \\
\text { Indicators) }\end{array}$ & $\begin{array}{c}\text { Continuous } \\
(-2.5-2.5)\end{array}$ \\
\hline Economic Growth & $\begin{array}{l}\text { Annual Economic Growth Rate (World Development } \\
\text { Indicators) }\end{array}$ & Continuous \\
\hline Population & $\begin{array}{l}\text { Natural log value of total population (World Development } \\
\text { Indicators) }\end{array}$ & Continuous \\
\hline Country Dummy & Dummy variable for each country & Binary $(0,1)$ \\
\hline
\end{tabular}


The Korean Journal of International Studies 15-2 | 246 